Determination of Antioxidant Activity of Ethanol Extract of Gölevez [(Colocasia esculenta (L.)] Tubers

\author{
Mehmet AKYÜZ \\ Kilis 7 Aralık University, Faculty of Science and Arts, Department of Chemistry, 79000, Turkey \\ https://orcid.org/0000-0001-7971-8389 \\ $\square$ : makyuz@kilis.edu.tr
}

\begin{abstract}
In this study, the antioxidant activity of the ethanolic extract of Colocasia esculenta tubers were determined by four different antioxidant tests including DPPH and ABTS radicals scavenging activities, metal chelating activity and reducing power. The scavenging effect of extract of $C$. esculenta tubers and standards on DPPH radical at the highest concentration $\left(600 \mu \mathrm{g} \mathrm{mL}^{-1}\right)$ decreased in the following order: Vitamin $\mathrm{C}>$ Trolox $>C$. esculenta $>\mathrm{BHA}$ and were found as 95.4, 93.6, 83.8 and $78.8 \%$, respectively. The scavenging effect of $C$. esculenta tuber extract and standards on ABTS radical at the highest concentration $\left(100 \mu \mathrm{g} \mathrm{mL}{ }^{-1}\right)$ decreased in the order: Trolox $=$ BHA $>C$. esculenta and were found as $100,100,94.6 \%$, respectively. The metal chelating capacity of extract of $C$. esculenta tubers and standards decreased in the order of $C$. esculenta $>\mathrm{BHA}>$ Trolox at lowest concentration $\left(100 \mu \mathrm{g} \mathrm{mL}^{-1}\right)$ and was found to be 78.0, 76.0, $63.5 \%$, respectively. Reducing power of extract of $C$. esculenta tubers and standards at the highest concentration $\left(600 \mu \mathrm{g} \mathrm{mL}^{-1}\right)$ followed the order: BHA $>$ Trolox $>C$. esculenta. Total phenolic compound and flavonoid amounts of $C$. esculenta tubers were designated as $2400 \mathrm{mg}$ $\mathrm{GAE} / \mathrm{kg}$ extract and $2050 \mathrm{mg} \mathrm{QE} / \mathrm{kg}$ extract, respectively.
\end{abstract}

Research Article
$\begin{array}{ll}\text { Article History } \\ \text { Received } \quad 09.07 .2019 \\ \text { Accepted } \quad: 23.08 .2019\end{array}$

Keywords
Colocasia esculenta
Antioxidant activity
Phenolic content
Radical scavenging

\title{
Gölevez [(Colocasia esculenta (L.)] Yumrularının Etanol Ekstresinin Antioksidan Aktivitesinin Belirlenmesi
}

\section{ÖZET}

Bu çalışmada Gölevez (Colocasia esculenta) yumrularının etanol ekstresinin antioksidan aktivitesi DPPH ve ABTS radikallerini giderme aktiviteleri, metal şelatlama aktivitesi ve indirgeme gücü gibi dört farkl antioksidan metotla belirlendi. C.esculenta yumrularının ekstreleri ve standartların en yüksek konsantrasyonda $(600 \mu \mathrm{g} \mathrm{mL}-1)$ DPPH radikali üzerindeki giderme etkisi Vitamin $\mathrm{C}$ $>$ Trolox $>$ C.esculenta $>$ BHA sirasina göre azaldı ve sirasıyla \% 95.4, 93.6, 83.8 ve 78.8 olarak bulundu. $C$. esculenta yumrularının ekstreleri ve standartların en yüksek konsantrasyonda $\left(100 \mu \mathrm{g} \mathrm{mL}^{-1}\right)$ ABTS radikali üzerindeki giderme etkisi Trolox $=\mathrm{BHA}>$ C.esculenta şeklinde azaldı ve sirasıyla \% 100, 100 ve 94.6 olarak bulundu. C.esculenta yumrularının ekstreleri ve standartların en düşük konsantrasyonda $(100 \mu \mathrm{g} \mathrm{mL}-1)$ metal şelatlama aktiviteleri $C$. esculenta $>\mathrm{BHA}>$ Trolox sirasına göre azaldı ve sirasıyla \% 78.0, 76.0 ve 63.5 olarak bulundu. C. esculenta yumrularının ekstreleri ve standartların en yüksek konsantrasyonda $(600 \mu \mathrm{g} \mathrm{mL}-1)$ indirgeme güçleri $\mathrm{BHA}>$ Trolox $>$ C.esculenta şeklinde siralandı. C.esculenta yumru ekstrelerinin toplam fenolik bileşik ve flavonoid miktarları sirasiyla $2400 \mathrm{mg}$ GAE/kg ekstre ve $2050 \mathrm{mgQE} / \mathrm{kg}$ ekstre olarak belirlendi.

\section{Araştırma Makalesi}

Makale Tarihçesi

Geliş Tarihi : 09.07.2019

Kabul Tarihi : 23.08.2019

Anahtar Kelimeler
Colocasia esculenta
Antioksidan aktivite
Fenolik içerik
Radikal giderme

To Cite : Akyüz M 2019. Determination of Antioxidant Activity of Ethanol Extract of Gölevez [( Colocasia esculenta (L.)] Tubers. KSU J. Agric Nat 22 (Suppl 2): 388-394. DOI: 10.18016/ksutarimdoga.vi.589216 


\section{INTRODUCTION}

Reactive Oxygen Species (ROS) are produced by various biochemical reactions in the human body and living organisms (Dehpour et al., 2009) during normal cellular functions (Mates, 2000). They become toxic when their levels increased (Ferreira et al., 2007). Excessive ROS and production of other radical molecules can damage biomolecules like proteins, carbohydrates, polyunsaturated fatty acids and DNA (Brighente et al., 2007). ROS also can cause many sicknesses like Parkinson's disease, cancer, diabetes, rheomatrid arthritis, aging, ischemia and liver disorders (Gowri and Madhavan, 2013). Gülçin (2010) reported that ROS play a role in more than 100 ailments related to excessive ROS. Antioxidants are often added to foods for retarding the oxidation process. These compounds can also clear free radicals and delay the advance of plenty of chronical sicknesses (Gülçin, 2012). Nowadays, butylated hydroxyanisole (BHA), butylated hydroxytoluene (BHT) and propyl gallate are among the most prevalent used antioxidants in food and pharmaceutical industries (Ak and Gülçin, 2008). However, BHA and BHT are both potent antioxidants but have been reported to have carcinogenetic activity (Madsen and Bertelsen, 1995). Therefore, interest in natural and safer antioxidants from natural products has been increased (Gülçin et al., 2012).

Colocasia esculenta is commonly known as Gölevez in Turkish folk medicine (Tanker et al., 2014). Also, it is grown in Souheast Asia, Cyprus and Turkey, especially in Mersin and Anamur (Tanker et al., 2014). Moreover, it was locally cultivated and used as a vegetable in India (Yadav et al., 2017). It belongs to the family of Araceae (Tuti et al., 2015) and is a tropical perennial plant, specific to Asia and the Pacific and widely spread out in tropical regions ( $\mathrm{Li}$ et al., 2014). Colocasia esculenta include dietary fiber, protein and vitamins including vitamin $\mathrm{C}$, thiamine, riboflavin and niacin (Yadav et al., 2017) and minerals such as iron, potassium, sodium and zinc (Nakharekar and Berde, 2016). Therefore, it is used as a source of protein, vitamins and starch (Sheikh and Tembhre, 2016). It is also recognized for its color, flavor and therapeutic value (Nakharekar and Berde, 2016). C. esculenta is reported to display some biological activities including antidiabetic, antiinflammatory (Li et al., 2014; Tuti et al., 2015; Yadav et al., 2017) antibacterial, antifungal, anthelmintic (Tuti et al., 2015), antioxidant and anticancer effects (Li et al., 2014; Yadav et al., 2017). Its edible corms and leaves are traditionally used for hepatic ailments (Nakharekar and Berde, 2016).

This study was carried out in order to determine the antioxidant activities of the ethanolic extracts of Colocasia esculenta (L.) tubers. The results were compared to standard antioxidants, which are Vitamin C, BHA and Trolox. At the same time, in the extract total phenolic compound and flavonoid amounts were detected.

\section{MATERIALS and METHODS}

\section{Materials and Extraction Procedure}

Colocasia esculenta (L.) tubers collected in Anamur, Mersin, and Mediterranean region of Turkey. The ethanolic extract was prepared according to Elmastaş et al., (2006). Peels of tubers thinly separated with a knife and the tubers dried in an oven at $40{ }^{\circ} \mathrm{C}$. Then 25 g Colocasia esculenta tuber was powdered by blender and mixed with $500 \mathrm{~mL}$ ethanol. Residual uptake was continued until the extraction solvent had lost its color. The extracts were combined and filtered. The ethanol was taken out with rotary evaporator at $40{ }^{\circ} \mathrm{C}$. The remaining extract transferred to a plastic flask and protected at $-20^{\circ} \mathrm{C}$ until used.

\section{DPPH free radical scavenging activity}

The DPPH free radical scavenging activity of the ethanolic extract was determined according to the Blois method (1958). For this purpose, $1 \mathrm{~mL}$ solution of DPPH (0.1 mM) was added to $3 \mathrm{~mL}$ of sample extract at various concentrations $(100-600 \mu \mathrm{g} \mathrm{mL}-1)$. The mixture incubated in room condition in dark about thirty minutes. The absorbance was spectrophotometrically recorded at $517 \mathrm{~nm}$. BHA, Trolox and Vitamin C were used as standard radical scavengers. Radical scavenging activity was calculated by following equation:

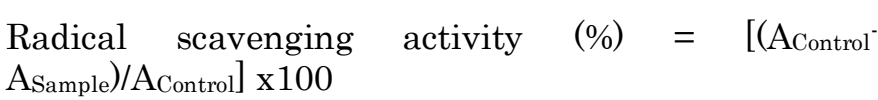

\section{ABTS radical scavenging activity}

ABTS radical scavenging effect of the ethanol extract was conducted as indicated in method of Re et al. (1999) and Gülçin (2009). Firstly, $2 \mathrm{mM} \mathrm{ABTS}$ and $2.45 \mathrm{mM} \mathrm{Na} 2 \mathrm{~S}_{2} \mathrm{O}_{8}$ solutions were mixed in a 1: 2 ratio and kept for 6 hours in the dark. The absorbance was read at $734 \mathrm{~nm}$. To adjust the absorbance, the melange was diluted with phosphate buffer $(0.1 \mathrm{M}$, $\mathrm{pH}: 7.4)$ when the absorbance was higher than 0.75 . The sample was then placed in test tubes at different concentrations (5-100 $\left.\mu \mathrm{g} \mathrm{mL}^{-1}\right)$. Phosphate buffer was added to obtain a total volume of $3 \mathrm{~mL}$. After this process, $1 \mathrm{~mL}$ of ABTS radicals was added to the mixture, then was vortexed and waited at room temperature for half an hour. Finally, its absorbance was spectrophotometrically recorded at $734 \mathrm{~nm}$. The scavenging capability of extract and standards were calculated from equation, which given below:
ABTS scavenging
effect
(\%) =
$\left[\left(\mathrm{A}_{\mathrm{Control}}\right.\right.$ 


\section{Metal chelating activity}

The chelating activity of $C$. esculenta tubers extracts and standards was determined in the light of literature (Dinis et al., 1994). Shortly, $0.4 \mathrm{~mL}$ of $\mathrm{FeCl}_{2}$ $(2 \mathrm{mM})$ and $0.4 \mathrm{~mL}$ of ferrozine $(5 \mathrm{mM})$ solutions were added to the extracts of varied concentrations (100$600 \mu \mathrm{g} \mathrm{mL}^{-1}$ ). The volume was completed to $4 \mathrm{~mL}$ with ethanol. The mixture was strongly vortexed and waited at room heat for $10 \mathrm{~min}$ and the absorbances were recorded by spectrophotometry at $562 \mathrm{~nm}$. Metal chelating effect of extract and standards were calculated from following equation:

Metal chelating effect $(\%)=\left[\left(\mathrm{A}_{\text {Control }}-\mathrm{A}\right.\right.$ Sample $\left.) / A_{\text {Control }}\right] \times 100$

\section{Reducing power}

The reducing power effect of the extract was measured by taking the procedure proposed by Oyaizu (1986). Varied concentrations of Colocasia esculenta (L.) tuber extracts (100-600 $\left.\mu \mathrm{g} \mathrm{mL}^{-1}\right)$ were put into test tubes and $2.5 \mathrm{~mL}$ phosphate buffer $(0.2$ $\mathrm{M}, \mathrm{pH}: 6.6)$ and $2.5 \mathrm{~mL}(1 \%)$ potassium ferricyanide solutions were added. The mixture was thoroughly mixed, incubated at $50{ }^{\circ} \mathrm{C}$ for $20 \mathrm{~min}$. Then $2.5 \mathrm{~mL}$ of TCA (10\%) solution was added to, and centrifuged for $10 \mathrm{~min}$ at $3000 \mathrm{rpm}$. Then $2.5 \mathrm{~mL}$ of supernatant and $0.5 \mathrm{~mL}$ of $\mathrm{FeCI}_{3}(0.1 \%)$ were mixed. The absorbance of the reaction mixture was read and recorded at 700 nm.

\section{Determination of total phenolic content}

Total phenolic compounds in $C$. esculenta tuber extracts were determined according to literature (Slinkard and Singleton, 1977) using gallic acid as a standard phenolic compound. Shortly, $1 \mathrm{~mL}$ of the extract solution was taken up in a volumetric flask and diluted with pure water $(46 \mathrm{~mL})$ and $1 \mathrm{~mL}$ FolinCiocalteu reagent was added and mixed well. After 3 minutes, $3 \mathrm{~mL}$ sodium carbonate $(2 \%)$ was added, then the mixture was allowed to stand for 2 hours at room temperature. The absorbance was measured at $760 \mathrm{~nm}$ in a spectrophotometer. The total phenolics in ethanolic extract was determined as milligram of gallic acid equivalent by using an equation that was obtained from a standard gallic acid graph.

\section{Determination of total flavonoid amount}

Total flavonoid quantification of the extracts was done as indicated in the literature (Moreno et al., 2000; Park et al., 1997) and was expressed as mg quercetin equivalent (QE). Briefly, $90 \mathrm{mg}$ of extract was prepared with $15 \mathrm{~mL}$ of ethanol and $1 \mathrm{~mL}$ of was taken to a test tube. Then $0.1 \mathrm{~mL}$ of aluminum nitrate $(10 \%)$ and potassium acetate $(1.0 \mathrm{M})$ were added and vortexed and the volume was completed with ethanol to obtain $4 \mathrm{~mL}$. It was waited at room heat for forty minutes and the absorbance was read at $415 \mathrm{~nm}$.

\section{RESULTS and DISCUSSION}

It has been reported that natural antioxidants show a large spectrum of biological effects such as antibacterial, antiviral, anti-inflammatory, antiallergic, antithrombotic and vasodilatory activities (Gülçin et al., 2010). Antioxidant capacity is commonly used to for characterizing foods or medicinal plants and their biologically active ingredients (Telci et al., 2009). Many antioxidant techniques and modifications are used to evaluate antioxidant capacity (Gülçin et al., 2004).

\section{DPPH free radical scavenging activity}

DPPH method is widely used to determine the antioxidant effect (Baydar, 2013). The method is based on electron-transfer that produces a purple solution in ethanol. If there is an antioxidant molecule in the ambit, the DPPH radical is reduced and leads to a colorless ethanol solution. Since the method is easy and fast, it may be useful to evaluate different products in terms of antioxidant activity at one time with spectrophotometry (Garlica et al., 2012).

C.esculenta tubers extracts scavenging effect and standards on the DPPH radical at the highest concentration $\left(600 \mu \mathrm{g} \mathrm{mL}^{-1}\right)$ decreased in the order of Vitamin $\mathrm{C}>$ Trolox $>C$. esculenta $>\mathrm{BHA}$ and were 95.4 , 93.6, 83.8 and $78.8 \%$, respectively and at lowest concentration $\left(100 \mu \mathrm{g} \mathrm{mL}^{-1}\right)$ decreased in the order of Trolox $>$ Vitamin $\mathrm{C}>\mathrm{BHA}>$ C. esculenta $>$ and were 88.7, $82.4,63.4$ and $24.2 \%$, respectively. The results were shown in figure 1.

\section{ABTS radical scavenging activity}

The ABTS radical scavenging method is often used to evaluate the antioxidant capability of foods (Fitriana et al., 2016) and biological samples (Shang et al., 2018). C. esculenta tubers extracts scavenging effect and standards at the lowest concentration $(5 \mu \mathrm{g} \mathrm{mL}-1)$ on ABTS radical decreased in order: Trolox $>$ BHA $>C$. esculenta and were 100, 96.6 and $6.3 \%$, respectively and at highest concentration $\left(100 \mu \mathrm{g} \mathrm{mL}^{-1}\right)$ decreased in the order of Trolox $=\mathrm{BHA}>C$. esculenta and were 100, 100 and $94.6 \%$, respectively. The results were shown in figure 2 .

\section{Metal chelating activity}

The metal chelating activity of an antioxidant prevents the oxidative formation and consequently oxidative detriment. Metal chelation plays an important role in antioxidant mechanisms as it reduces the transition metal concentration. These 
ions are powerful catalysts and are capable of initiation lipid peroxidation particularly in cell membranes (Ruiz Ruiz et al., 2015). The metal chelating effect of $C$. esculenta tubers and standards decreased in the order of $C$. esculenta $>\mathrm{BHA}>$ Trolox at the lowest concentration $\left(100 \mu \mathrm{g} \mathrm{mL}^{-1}\right)$ and were found as 78.0, 76.0 and $63.5 \%$, respectively and decreased in the order of Trolox $>C$. esculenta $>\mathrm{BHA}$ at the highest concentration $\left(600 \mu \mathrm{g} \mathrm{mL}^{-1}\right)$ and were found as $71.5,68.0$ and $64.0 \%$, respectively. The results were shown in figure 3 .

\section{Reducing power}

Reducing power of a compound may function as an important reflection of its potency antioxidant capacity (Benslama and Harrar, 2016). Reducing power of $C$. esculenta tubers and standards at the highest concentration (600 $\left.\mu \mathrm{g} \mathrm{mL}^{-1}\right)$ followed the order: $\mathrm{BHA}>$ Trolox $>C$. esculenta, respectively and at the lowest concentration $\left(100 \mu \mathrm{g} \mathrm{mL}^{-1}\right)$ followed the order: $\mathrm{BHA}>$ Trolox $>$ C.esculenta, respectively. The results were shown in figure 4 .

\section{Determination of total phenolic compound amount}

Phenolics are the most important compounds that were found in plants (Elmastaş et al., 2006). It was emphasized that the antioxidant activity of the plants was caused by phenolic compounds (Mathangi and Prabhakaran, 2013). These particularly have strong antioxidant, antimicrobial, and antiviral effects and make strong the organisms and prevent diseases (Liaudanskas et al., 2017). Total phenolic compound amount of $C$. esculenta was determined as $2400 \mathrm{mg}$ $\mathrm{GAE} / \mathrm{kg}$ extract.

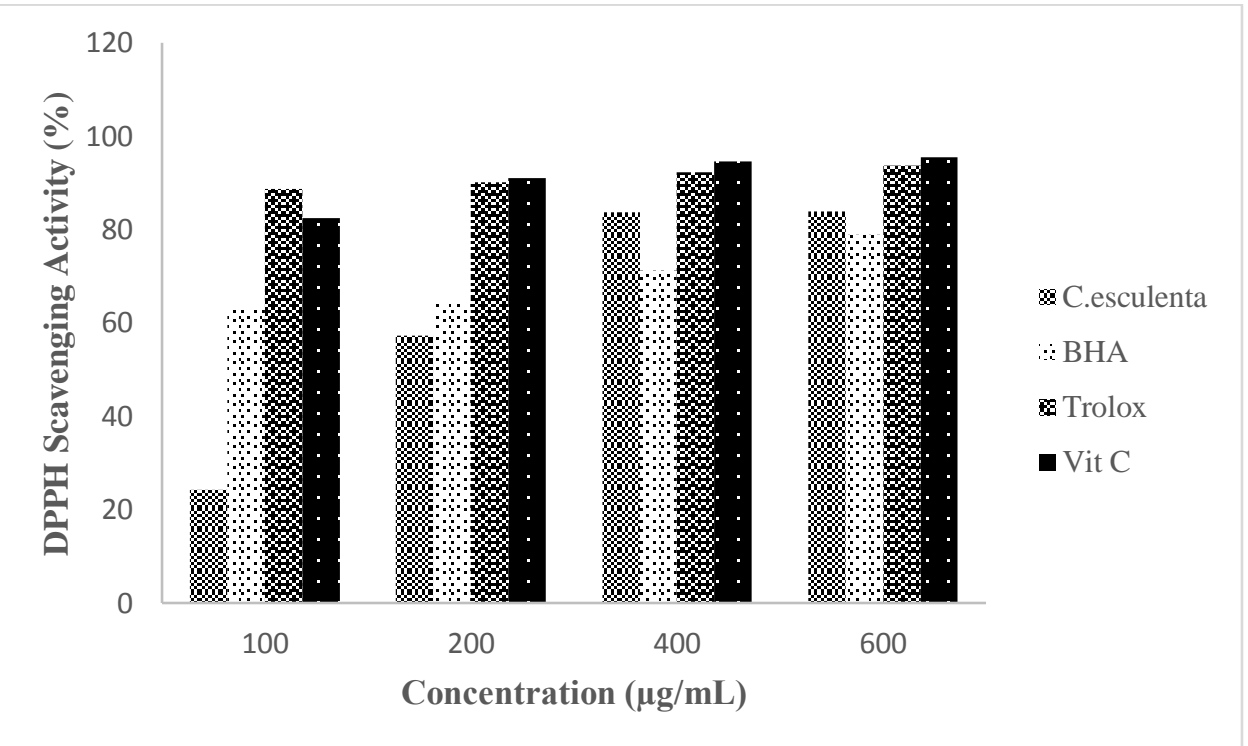

Figure 1. DPPH free radical scavenging activity of Colocasia esculenta tubers and standards

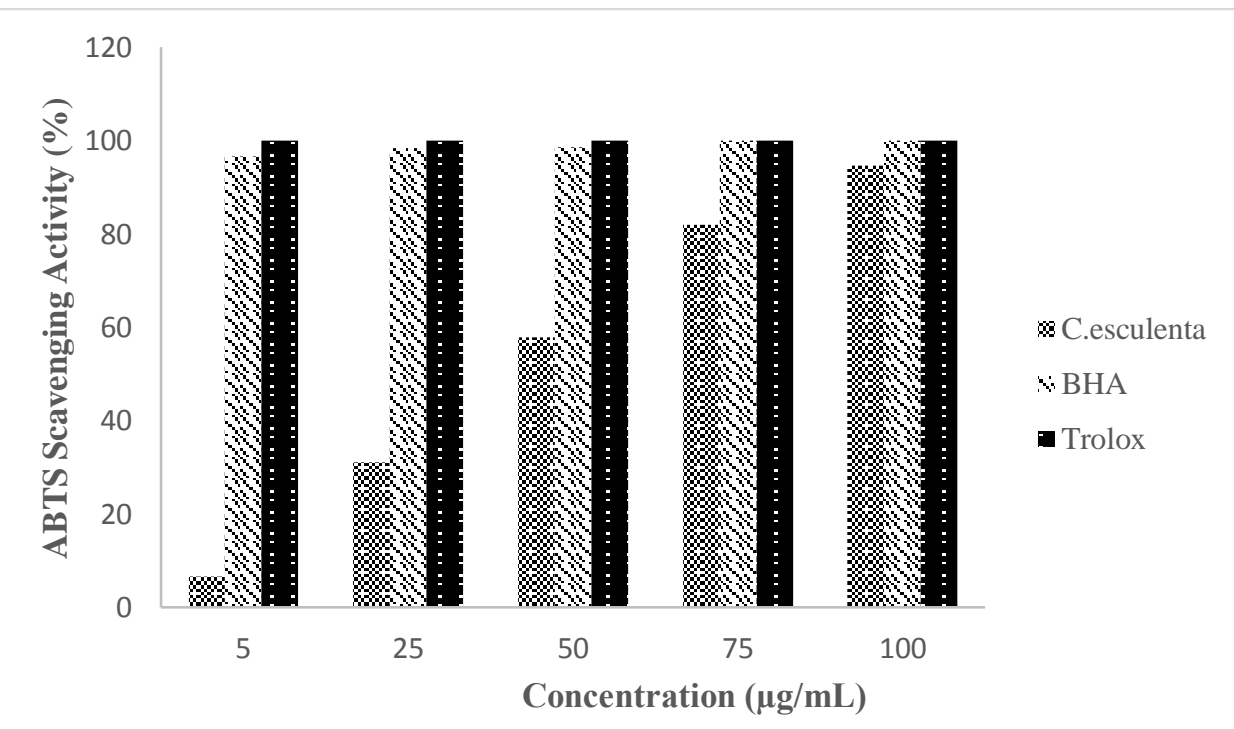

Figure 2. ABTS scavenging activity of Colocasia esculenta tubers and standards 


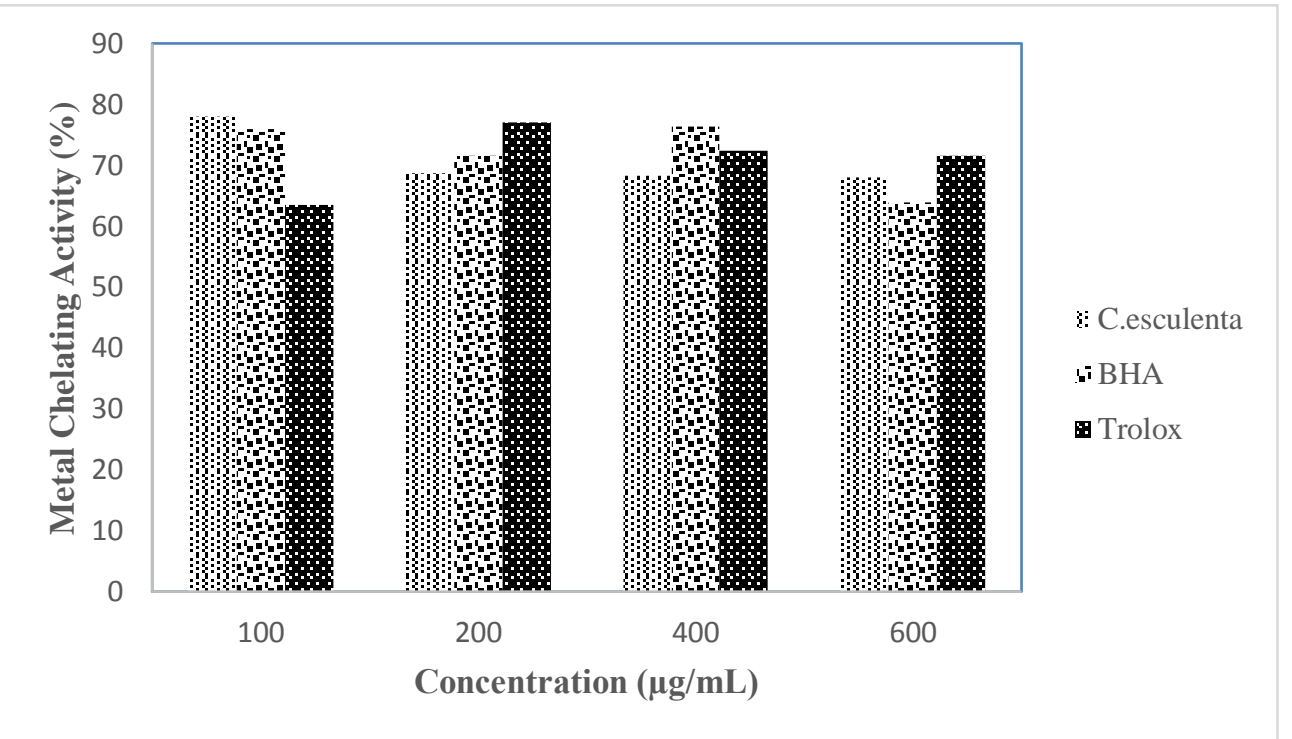

Figure 3. Metal chelating activity of Colocasia esculenta tubers and standards

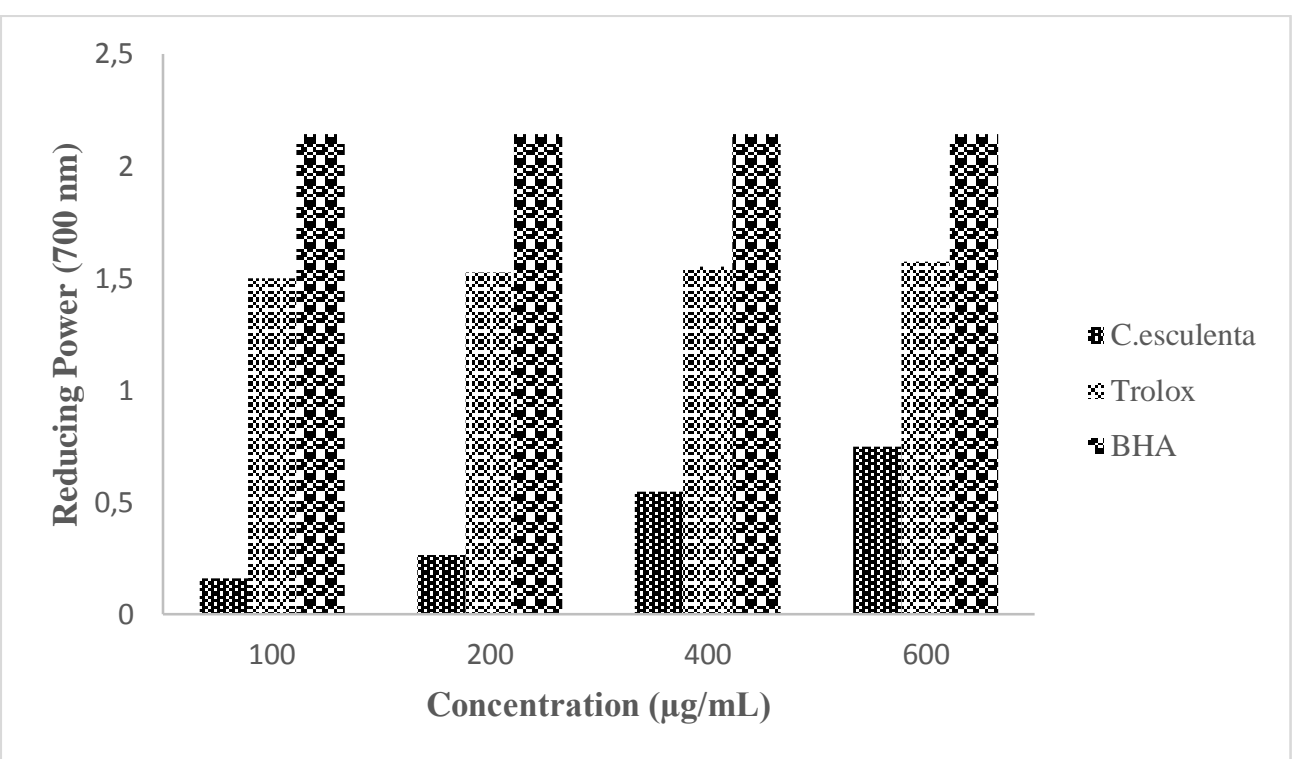

Figure 4. Reducing power activity of Colocasia esculenta tubers and standards

\section{Determination of total flavonoid amount}

Flavonoids are responsible for antioxidant effects and prevent the growth of bacteria and viruses and provide resistance to cancer and heart attack (Baydar, 2013). It has been reported that dietary flavonoids play a protective role against coronary heart disease (Khan et al., 2014). Total flavonoid amount of $C$. esculenta tuber was detected as 2050 $\mathrm{mg} \mathrm{QE} / \mathrm{kg}$ extract.

As a result, in this study, it was observed that the effective antioxidant activity of $C$. esculenta tuber extract was depending on its concentration. The plant has a powerful antioxidant activity to remove DPPH and ABTS radicals at the highest concentrations. Reducing power was also determined at high concentration but lower than the standards (Trolox and BHA). On the contrary at lowest concentration the plant showed higher metal chelating activity than standards (Trolox and BHA). It is thought that the radical removal activity of $C$. esculenta tuber extract was due to the flavonoid and phenolic compounds it contains. Due to radical scavenging activities and phenolic compounds, $C$. esculenta tubers may be preferred as an alternative source instead of synthetic antioxidants in food industry.

\section{REFERENCES}

Ak T, Gülçin İ 2008. Antioxidant and radical scavenging properties curcumin. ChemicoBiological Interactions, 174: 27-37.

Baydar H 2013. Tibbi ve Aromatik Bitkiler Bilimi ve Teknolojisi (Genişletilmiş 4. Baskı). Süleyman Demirel Üniversitesi, Ziraat Fakültesi Yayınları No: 51, Isparta, $303 \mathrm{~s}$.

Benslama A, Harrar A 2016. Free radicals scavenging activity and reducing power of two Algerian Sahara medicinal plants extracts. International 
Journal of Herbal Medicine, 4 (6): 158-161.

Blois MS 1958. Antioxidant determinations by the use of a stable free radical. Nature, 26, 1199-1200.

Brighente IMC, Dias M, Verdi LG, Pizzolatti MG 2007. Antioxidant activity and total phenolic content of some Brazilian Species. Pharmaceutical Biology, 45 (2): 156-161.

Dehpour A.A, Ebrahimzadeh MA, Fazel NS, Mohammad NS 2009. Antioxidant activity of the methanol extract of Ferula assafoetida and its essential oil composition, Grasas Y Aceites, 60 (4): 405-412.

Dinis TCP, Madeira VMC, Almeida LM 1994. Action of phenolic derivates (acetoaminophen, salycilate, and 5-aminosalycilate) as inhibitors of membrane lipid peroxidation and as peroxyl radical scavengers. Archives of Biochemistry and Biophysics, 315: 161-169.

Elmastaş M, Gülçin İ, Beydemir Ş, Küfrevioğlu Öİ, Aboul-Enein, HY 2006. A study on the in vitro antioxidant activity of juniper (Juniperus Communis L.) fruit extracts. Analytical Letters, 39, 47-65.

Ferreira Isabel C.F.R, Baptista P, Vilas-Boas M, Barros L 2007. Free radical scavenging capacity and reducing power of wild edible mushrooms from northeast Portugal: Individual cap and stipe activity. Food Chemistry, 100: 1511-1516.

Fitriana WD, Ersam T, Shimizu K, Fatmawati S 2016. Antioxidant activity of Moringa Oleifera extracts. Indonesian Journal of Chemistry, 16 (3): 297-301.

Garlica EJ, Oldoni TLC, Alencar SM, de Reis A, Loguercio AD, Grande RHM 2012. Antioxidant activity by DPPH assay of potential solutions to be applied on Bleached Teeth. Brazilian Dental Journal, 23(1): 22-27.

Gowri R, Madhavan V 2013. Evaluation of antioxidant activity of ethanolic extract of Sphaeranthus amaranthoides Burm. International Drug Development and Research, 5(4): 320-329.

Gülçin İ 2009. Antioxidant activity of L-adrenaline: A structure-activity insight. Chemico-Biological Interactions, 179: 71-80.

Gülçin İ 2010. Antioxidant properties of resveratrol: A structure-activity insight. Innovative Food Science and Emerging Technologies, 11: 210-218.

Gülçin I 2012. Antioxidant activity of food constituents: an overview. Archives of Toxicology, 86, 345-391.

Gülçin İ, Elmastaş M, Aboul-Enein HY 2012. Antioxidant activity of cloveoil-A powerful antioxidant source, Arabian Journal of Chemistry, 5: 489-499.

Gülçin İ, Huyut H, Elmastaş M, Aboul-Enein HY 2010. Radical scavenging and antioxidant activity of tannic acid. Arabian Journal of Chemistry, 3: $43-53$.
Gülçin İ, Şat İG, Beydemir Ş, Elmastaş M, Küfrevioglu Öİ 2004. Comparison of antioxidant activity of clove (Eugenia caryophylata Thunb) buds and lavender (Lavandula stoechas L.). Food Chemistry 87, 393-400.

Khan N, Al Daghri, NM, Al Ajlan AS, Alokail MS 2014. The use of natural and derived sources of flavonoids and antioxidants in Saudi Arabia. Integrative Food Nutrition Metabolism, 1(2): 100106.

Li HM, Hwang SH, Kang BG, Hong JS, Lim SS 2014. Inhibitory effects of Colocasia esculenta (L.) Schott constituents on aldose reductase, Molecules, 19: 13212-13224.

Liaudanskas M, Zymone K, Viškelis J, Klevinskas A, Janulis V 2017. Determination of the phenolic composition and antioxidant activity of pear extracts. Hindawi Journal of Chemistry, Article ID, 7856521: 1-9.

Madsen HL, Bertelsen G 1995. Species as antioxidants. Trends in Food Science and Technology, 6 (8): 271-277.

Mates JM 2000. Effects of antioxidant enzymes in the molecular control of reactive oxygen species toxicology. Toxicology, 153: 83-104.

Mathangi T, Prabhakaran, P 2013. DPPH free radical scavenging activity of the extracts of the aquatic fern Marsilea quadrifolia Linn. International Journal of Current Microbiology and Applied Sciences, 2(10): 534-536.

Moreno MIN, Isla MI, Sampietro AR, Vattuone MA 2000. Comparison of the free radical scavenging activity of propolis from several regions of Argentina. Journal of Ethnopharmacol, 71: 109114.

Nakharekar VG, Berde CV 2016. Secondary metabolites and nutritional value profiling of Colocasia esculenta. World Journal of Pharmaceutical Research, 5 (10): 709-720.

Oyaizu M 1986. Studies on product of browning reaction prepared from glucosamine. Japan Journal of Nutrition, 44: 307-315.

Park YK, Koo MH, Ikegaki M, Contado, JL 1997. Comparison of the flavonoid aglycone contents of Apis mellifera propolis from various regions of Brazil. Arquivos de Biologia e Technologia 40 (1): 97-106.

Re R, Pellegrini N, Proteggente A, Pannala A, Yang M, Rice-Evans C 1999. Antioxidant activity applying an improved ABTS radical cation decolorization assay. Free Radical Biology and Medicine 26: 1231-1237.

Ruiz Ruiz, JC, Moguel Ordoñez, YB, Matus Basto, A, Segura Campos, MR 2015. Antioxidant capacity of leaf extracts from two Stevia rebaudiana Bertoni varieties adapted to cultivation in Mexico. Nutricion hospitalaria 31(3): 1163-1170. 
Shang HM, Zhou HZ, Yang JY, Li R, Song H, Wu HX 2018. In vitro and in vivo antioxidant activities of inulin. Plos One, 2, 1-12.

Sheikh MA, Tembhre M, 2016. Preliminary phytochemical screening, in vitro antioxidant activity, total phenolic and total flavonoid contents of Colocasia esculenta leaf extract. Asian Journal of Experimental Sciences 30: (1\&2): 39-43.

Slinkard K, Singleton VL 1977. Total phenol analyses: Automation and comparison with manual methods. American Journal of Enology and Viticulture, 28: 49-55.

Tanker N, Koyuncu M, Coşkun M 2014. Farmasötik Botanik, Ankara Üniversitesi Eczacılık Fakültesi Yayınları No: 105, Ankara, 424s.
Telci İ, Elmastas M, Sahin A 2009. Chemical composition and antioxidant activity of Ocimum minimum essential oils. Chemistry of Natural Compounds, 45 (4): 568-571.

Tuti MD, Pal RS, Arun Kumar R, Bist JK, Bhatt JC 2015. Colocasia based cropping systems affects the antioxidant properties and productivity of colocasia [Colocasia esculenta (1.) schott] tuber. The Bioscan an International Quaterly Journal of Life Sciences, 10 (1): 117-123.

Yadav M, Kushawaha DK, Chatterji S, Watal G 2017. Assessment of antioxidant activity and phytochemical screening of Colocasia esculenta corm. International Journal of Pharmaceutical Sciences and Research, 8(4): 1758-1764. 